\title{
Translation and validation of the inflammatory bowel disease fatigue (IBD-F) patient self-assessment questionnaire
}

\author{
Ariel Liebert ${ }^{1,2}$, Aleksandra Wileńska ${ }^{1,2}$, Władysława Czuber-Dochan ${ }^{3}$, Maria Kłopocka $^{1,2}$ \\ ${ }^{1}$ Department of Gastroenterology and Nutrition Disorders, Collegium Medicum in Bydgoszcz, Nicolaus Copernicus University \\ in Torun, Poland \\ ${ }^{2}$ Gastroenterology Clinic, Jan Biziel University Hospital No. 2, Bydgoszcz, Poland \\ ${ }^{3}$ Florence Nightingale Faculty of Nursing, Midwifery, and Palliative Care, King's College London, United Kingdom
}

Gastroenterology Rev 2021; 16 (2): 136-143

DOI: https://doi.org/10.5114/pg.2021.106665

Key words: fatigue, inflammatory bowel disease.

Address for correspondence: Ariel Liebert PhD, Department of Gastroenterology and Nutrition Disorders, Collegium Medicum, Nicolaus Copernicus University, Jan Biziel University Hospital No. 2, 75 Ujejskiego St, 85-168 Bydgoszcz, Poland, phone: +48 523655284 , e-mail: liebert@cm.umk.pl

\begin{abstract}
Introduction: Inflammatory bowel disease (IBD) is a group of chronic gastrointestinal diseases with frequent systemic complications that are incurable according to current knowledge. These diseases adversely affect various areas of life, lowering patients' quality of life. One of the most frequently reported symptoms is fatigue.

Aim: Translation and validation of the IBD-F patient self-assessment scale with a Polish IBD population.

Material and methods: After consent from the author of the questionnaire had been obtained, the questionnaire was translated using the forward- and back-translation method. After arriving at the final Polish version of the questionnaire and ensuring that the questions and statements were comprehensible, the questionnaire was validated with a group of 129 IBD patients.

Results: High values of intraclass correlation coefficient (ICC) were achieved for overall results in both parts of the IBD-F questionnaire between test and retest (values exceeding 0.75). A high Cronbach's $\alpha$ consistency coefficient was achieved for the entire IBD-F questionnaire, both in the test and in the retest ( 0.968 and 0.975 , respectively). Broken down into parts, Cronbach's $\alpha$ coefficient for Section I (presence and severity of fatigue) of the IBD-F questionnaire was 0.883, and for Section II (impact of fatigue on the person's life) it was 0.966 . All patients evaluating the Polish version of the IBD-F questionnaire deemed the content of the questions comprehensible.

Conclusions: The analysis of the results obtained, the Polish version of the IBD-F questionnaire was considered valid, reliable, and clinically useful.
\end{abstract}

\section{Introduction}

Inflammatory bowel diseases (IBD), which include Crohn's disease (CD) and ulcerative colitis (UC), are a group of chronic, currently incurable gastrointestinal disorders of yet unexplained aetiopathogenesis. According to the current state of knowledge, their occurrence is determined by coinciding environmental and immunological factors, genetic predispositions, as well as qualitative and quantitative disturbance in the gastrointestinal microbiota [1-3]. IBD prevalence and incidence are constantly on the rise. In 2017, the number of IBD patients around the world was estimated at over 6.8 million $[4,5]$. The disease may develop at any age, but peak incidence is observed between 15 and 29 years of age $[6,7]$.

IBD is characterised by its chronic course, with alternating periods of exacerbation and remission of the symptoms. The durations of these periods vary and are difficult to predict in individual patients, whereas the clinical picture depends on the form and location of the disease $[7,8]$. The main gastrointestinal symptoms are abdominal pain and chronic diarrhoea, sometimes with a speck of blood and/or mucus. Many patients suffer from numerous complications, both in the gastrointestinal tract and systemic, as well as from extraintestinal symptoms of the disease, which often appear months 
or years before establishing the correct diagnosis [9, 10]. Pharmacological treatment is predominantly based on using immunosuppressants, glucocorticoids, and biologic therapies with various levels of risk of adverse effects $[11,12]$. In the case of failure, loss of response, or contraindications to treatment, surgical treatment, often repeated, is required $[13,14]$.

The chronic and systemic nature of IBD adversely affects various areas of patients' lives, lowering their overall quality of life. Available literature data shows that one of the most frequently reported problems associated with the disease is fatigue $[15,16]$. Chronic fatigue experienced by the patients during periods of disease activity and during clinical remission alike constitutes one of the major problems in their day-to-day life. Proper handling of these cases requires primarily a reliable diagnosis and consideration of possible causes of the symptom [17].

There are many questionnaires and scales available for determination of fatigue intensity; however, most of them have not been validated in a group of IBD patients and do not take the specificity of these patients' problems into account. The first fatigue assessment questionnaire dedicated to this group of patients is the Inflammatory Bowel Disease Fatigue (IBD-F) patient self-assessment scale [17].

\section{Aim}

The aim of this study was to translate (using the forward- and back-translation method) and subsequently validate (using the test-retest method) the Polish version of the IBD-F questionnaire in a group of IBD patients.

\section{Material and methods}

Work on preparation of the Polish version of the IBD-F scale, originally developed in the United Kingdom (UK), began with the translation process. A standard forward- and back-translation procedure was used. After consent from the author of the original version of the questionnaire had been obtained, it was translated into Polish by 2 independent translators fluent in English, both being native speakers of Polish, one of whom has had medical education and experience of work with IBD patients, and the other had no medical education (forward translation). In the next step, a group of 4 experts (a gastroenterologist, 2 nurses, and a pharmacist - expert panel) compared the 2 versions of the questionnaire and drew up its initial language version. After the Polish version had been accepted by all members of the expert panel, it was back-translated (from Polish into English) by 2 independent persons being native speakers of English and having a good command of Polish, one of whom had medical education (backward translation). In the next step, the expert panel compared the back-translated English versions of the scale with the original version. After confirming that the meanings of the statements/questions had not been changed in the translation process, the final Polish version of the IBD-F scale was agreed. Afterwards a group of 10 persons (physicians, nurses, dieticians) were asked to evaluate the comprehensibility of the questions and statements and to provide their comments as to the content and graphic option of the questionnaire, if any. After acceptance of this version, the validation process was commenced. One hundred and twenty-nine patients participated in the study (Table I).

The validation was conducted using the test-retest method with an interval of 14 days. The first assessment with the use of the IBD-F scale was performed at the centre. After that, depending on the patients' further appointments, various methods of retesting after 14 days were used - retesting directly at the centre, by means of electronic mail, or by the patients themselves at home (after a telephone reminder to complete the questionnaire) and returning the questionnaire during the following appointment.

In addition, the study group were asked to evaluate the following: a) their comprehension of the questions (answers: yes or no); b) the graphical design; c) the ease of questionnaire completion; and d) the time required to complete the questionnaire. Items $b$ - $d$ were to be evaluated on a 5 -point scale (with 1 being the worst and 5 being the best value).

The intraclass correlation coefficients (ICC) value served the purpose of checking the reliability of answers to individual questions of the questionnaire between the test and the retest. Cronbach's $\alpha$ coefficient was used to evaluate the consistency of answers in the questionnaires.

All calculations were performed using the R statistical package, version 3.3 (R Development Core Team 2017).

The study was approved by the local Collegium Medicum Ethics Committee (Ref. number: KB 182/2016).

Table I. Characteristics of the study group (IQR; min.max.)

\begin{tabular}{|c|c|c|}
\hline Variable & Value (UC) & Value (CD) \\
\hline \multirow[t]{2}{*}{ Sex } & 오․ 6 \% $(N=30)$ & ㅇ $45.2 \%(N=33)$ \\
\hline & o $46.4 \%(N=26)$ & o $54.8 \%(N=40)$ \\
\hline Age [years] & $35(18-71)$ & $28(18-67)$ \\
\hline
\end{tabular}

IQR - median, UC - ulcerative colitis, CD - Crohn's disease, $N$-number of patients. 


\section{Results}

The IBD-F questionnaire was completed again (test-retest) by 103 (79.8\%) out of the total of 129 subjects, who took part in the first round of testing.

Table II includes a comparison of ICC values for the overall results achieved in the IBD-F questionnaire for both the Polish and the original English version.

ICC in the Polish and English version are similar for all but one question. A pronounced difference was found in question 2.10 'I was unable to do as much physical exercise as I wanted because of fatigue'. In the Polish version of the questionnaire, the ICC is 0.659 (95\% Cl: $0.53-0.758)$, whereas in the original work by Czuber-Dochan the consistency was greater and amounted to 0.88 (95\% Cl: 0.78-0.94) [17]. In general, an ICC value (lower than 0.6) was achieved for 2 out of 5 questions $(1.1,1.3)$ in section 1 and in 4 out of 30 statements $(2.3,2.7,2.17,2.18)$ of the closed-ended part of the IBD-F questionnaire in its Polish version. Additionally, statements 1.1, 1.3, 2.7 in the English version also had ICC values below 0.6. Good intraclass correlation (between 0.6 and 0.75 ) was achieved for 3 questions and 21 statements, and excellent correlation ( 0.75 and above) was achieved for the remaining 5 statements $(2.9,2.12,2.22,2.23,2.24)$.

Table II. Comparison of ICC values for the overall results for both the Polish and the original versions of the IBD-F scale

\begin{tabular}{lcc} 
Variable & ICC $(95 \% \mathrm{Cl})$ & N \\
\hline IBD-F $(\mathrm{PL})$ - part I & $0.77(0.68-0.84)$ & 97 \\
\hline IBD-F $(\mathrm{ENG})$ - part I & $0.74(0.54-0.86)$ & 36 \\
\hline IBD-F $(\mathrm{PL})$ - part II & $0.84(0.77-0.89)$ & 98 \\
\hline IBD-F $(\mathrm{ENG})$ - part II & $0.83(0.69-0.91)$ & 35
\end{tabular}

ICC - intraclass correlation coefficient, $95 \% \mathrm{Cl}-95 \%$ confidence interval, $N$ - number of complete answers, $P L$ - Polish version of the questionnaire, ENG - English version of the questionnaire [17].

Table III. Values of Cronbach's $\alpha$ coefficient in the first measurement (test) and retest (after 14 days) for the entire scale and individual parts (I and II)

\begin{tabular}{lcc} 
Variable & Cronbach's $\alpha(95 \% \mathrm{CI})$ & $\boldsymbol{N}$ \\
\hline IBD-F (whole) - test & $0.968(0.95-0.98)$ & 48 \\
\hline IBD-F (whole) - retest & $0.975(0.97-0.98)$ & 78 \\
\hline IBD-F part I - test & $0.883(0.85-0.92)$ & 119 \\
\hline IBD-F part I - retest & $0.898(0.86-0.93)$ & 101 \\
\hline IBD-F part II - test & $0.966(0.95-0.98)$ & 50 \\
\hline IBD-F part II - retest & $0.971(0.96-0.98)$ & 80
\end{tabular}

95\% Cl-95\% confidence interval, $\mathrm{N}$ - number of complete answers.
Values of Cronbach's $\alpha$ coefficient were calculated for the entire questionnaire as well as for its individual parts in the first measurement (test) and in the assessment after 14 days (retest). The results are shown in Table III.

All patients evaluating the IBD-F questionnaire deemed the questions and statements included therein comprehensible $(N=118)$. The following questionnaire elements: graphic design, ease of completion, and time required to complete, were evaluated on a scale of 1 to 5 points. The ease of completion was the most highly rated element (mean: 4.5). The other 2 elements were rated slightly lower (mean: 4.3). The results are presented in Table IV.

\section{Discussion}

The inflammatory bowel disease fatigue (IBD-F) patient self-assessment scale consists of 3 parts. Part I consists of 5 questions and covers general assessment of fatigue, its severity, frequency, and duration in the preceding 2 weeks. Part II is used to assess the impact of inflammatory bowel disease fatigue on day-to-day activity, also in the course of the preceding 2 weeks. It comprises 30 statements, 6 of which give the option to select N/A (not applicable), for instance if the patient no longer attends school or is not a driver. The questions and statements are assessed on a 5-point scale according to the patients' agreement with individual answers or statements. It is very important that the patients answer all of the questions. The sections are assessed and scored separately. Possible scores are 0-20 and 0-120 in part I and II, respectively. If the 'not applicable - N/A' option is checked (questions 3, 4, 9, 12, 13, 14), a corrected result has to be calculated from the following formula: Corrected result $=$ actual total result/(120 - number of $\mathrm{N} / \mathrm{As} \times 4) \times 120$.

Part III, which is the last part, differs from the preceding parts significantly. It consists of 5 unscored and mostly open-ended questions. It helps to identify causes and other factors affecting the feeling of fatigue.

Table IV. Independent evaluation of the IBD-F questionnaire by the patients

\begin{tabular}{lcc} 
Variable & Parameter & $\boldsymbol{N}$ \\
\hline $\begin{array}{l}\text { Comprehensibility } \\
\text { of questions } \\
\text { and statements }\end{array}$ & Yes & 118 \\
\cline { 2 - 3 } Graphical design & Mean (SD) & 0 \\
\hline Ease of completion & Mean (SD) & $4.3(0.8)$ \\
\hline Time required to complete & Mean (SD) & $4.3(0.9)$
\end{tabular}

$N$ - number of complete answers, SD - standard deviation. 
Questions from this section may be used in consultations with healthcare professionals [17].

The authors of the original English version of the questionnaire have not set any score thresholds. However, a score of 0 attained in part I means that the patient did not have any problems with fatigue within the preceding 2 weeks, so no action in this respect is required, and the other parts of the questionnaire need not to be completed [17].

In order to evaluate the repeatability of the results achieved by means of the IBD-F questionnaire, the test was repeated after 14 days. A large percentage of the patients from the study group completed the questionnaire again. The comparison of the ICC values with results of the study by Czuber-Dochan et al. (Table II) attests to a high level of agreement between the Polish and English versions of the questionnaire [17]. A comparison of ICC values for overall results achieved in the IBD-F questionnaire in part one and in part two indicates excellent consistency of test and retest answers (values exceeding 0.75).

The internal consistency of the IBD-F questionnaire was evaluated by means of Cronbach's $\alpha$ coefficient. A high consistency coefficient for the entire IBD-F questionnaire was achieved, both in the test and in the retest ( 0.968 and 0.975 , respectively). Broken down into parts, Cronbach's $\alpha$ coefficient for Section I of the IBD-F questionnaire was 0.883 (0.91 in the English version) and the consistency coefficient for Section II was 0.966 (0.98 in the English version) [17]. Of note is the fact that, in our study, values of Cronbach's $\alpha$ coefficient for both parts of the questionnaire were slightly higher in the retest (Table III).

All patients evaluating the Polish version of the IBD-F questionnaire deemed the content of the questions and statements comprehensible. The graphic design, ease of completion, and time required to complete the scale were also highly rated.

To conclude the analysis of the results obtained, the Polish version of the IBD-F questionnaire is considered reliable and clinically useful.

The lack of score thresholds in the assessment of fatigue intensity is most likely caused by multifactorial basis of the fatigue, often also contingent on environmental, social, and cultural factors. This is largely related to place of residence [18-20]. An assessment of fatigue among the population of Polish IBD patients seems to be the next step because currently there are no such data.

\section{Conclusions}

The Polish version of the IBD-F scale, after the translation and validation process, can be used as a clinical or research tool in the population of Polish IBD patients. The scale was translated and validated with the participation of clinicians working in IBD and people diagnosed with IBD in Poland. The IBD-F scale is deemed valid and reliable for use with Polish patients.

\section{Acknowledgments}

The data processing and statistical analysis was financed by an EGIS scientific grant.

Appendix 1 - IBD-F Polish version.

IBD-F English version - Czuber-Dochan W, Norton C, Bassett P, et al. Development and psychometric testing of inflammatory bowel disease fatigue (IBD-F) patient self-assessment scale. J Crohn's Colitis. 2014; 8: 1398-406.

\section{Conflict of interest}

The authors declare no conflict of interest.

\section{References}

1. Guan Q. A comprehensive review and update on the pathogenesis of inflammatory bowel disease. J Immunol Res 2019; 2019: 7247238.

2. Lee SH, Kwon J, Cho ML. Immunological pathogenesis of inflammatory bowel disease. Intest Res 2018; 16: 26-42.

3. Godfrey M, Lee NR. Memory profiles in Down syndrome across development: a review of memory abilities through the lifespan. J Neurodev Disord 2018; 10: 5.

4. Alatab S, Sepanlou SG, Ikuta K, et al. The global, regional, and national burden of inflammatory bowel disease in 195 countries and territories, 1990-2017: a systematic analysis for the Global Burden of Disease Study 2017. Lancet Gastroenterol Hepatol 2020; 5: 17-30.

5. Ng SC, Shi HY, Hamidi N, et al. Worldwide incidence and prevalence of inflammatory bowel disease in the 21 st century: a systematic review of population-based studies. Lancet 2017; 390: 2769-78.

6. Prelipcean CC, Mihai C, Gogalniceanu P, et al. What is the impact of age on adult patients with inflammatory bowel disease? Clujul Med 2013; 86: 3-9.

7. Nasseri-Moghaddam S. Inflammatory bowel disease. Middle East J Dig Dis 2012; 4: 77-89.

8. Baumgart DC, Sandborn WJ. Crohn's disease. Lancet 2012; 380: 1590-605

9. Levine JS, Burakoff R. Extraintestinal manifestations of inflammatory bowel disease. Gastroenterol Hepatol 2011; 7: 235-41.

10. Harbord M, Annese V, Vavricka SR, et al. The first European Evidence-based consensus on extra-intestinal manifestations in inflammatory bowel disease. J Crohn's Colitis 2016; 10: 23954.

11. Torres J, Bonovas S, Doherty G, et al. ECCO guidelines on therapeutics in Crohn's disease: medical treatment. J Crohn's Colitis 2020; 14: 4-22.

12. Harbord M, Eliakim R, Bettenworth D, et al. Third European evidence-based consensus on diagnosis and management of ulcerative colitis. Part 2: current management. J Crohn's Colitis 2017; 11: 769-84. 
13. Peyrin-Biroulet L, Panés J, Sandborn WJ, et al. Defining disease severity in inflammatory bowel diseases: current and future directions. Clin Gastroenterol Hepatol 2016; 14: 348-54.e17.

14. Adamina M, Bonovas S, Raine T, et al. ECCO guidelines on therapeutics in Crohn's disease: surgical treatment. J Crohn's Colitis 2020; 14: 155-68.

15. Habibi F, Habibi M, Gharavinia A, et al. Quality of life in inflammatory bowel disease patients: a cross-sectional study. J Res Med Sci 2017; 22: 104.

16. Van Langenberg DR, Gibson PR. Systematic review: fatigue in inflammatory bowel disease. Aliment Pharmacol Ther 2010; 32: 131-43.

17. Czuber-Dochan W, Norton C, Bassett P, et al. Development and psychometric testing of inflammatory bowel disease fatigue (IBD-F) patient self-assessment scale. J Crohn's Colitis 2014; 8: 1398-406.

18. Haß U, Herpich C, Norman K. Anti-inflammatory diets and fatigue. Nutrients 2019; 11: 2315.

19. Louati K, Berenbaum F. Fatigue in chronic inflammation a link to pain pathways. Arthritis Res Ther 2015; 17: 254.

20. Finsterer J, Mahjoub SZ. Fatigue in healthy and diseased individuals. Am J Hosp Palliat Med 2014; 31: 562-75.

Received: 19.07 .2020

Accepted: 10.08 .2020 


\title{
Appendix
}

\section{Ankieta samodzielnej oceny zmęczenia u osób z chorobami zapalnymi jelit (IBD-F)}

Data:

\author{
Godzina:
}

\section{Część I - Skala oceny zmęczenia}

Ta część kwestionariusza dotyczy zmęczenia, jego poziomu, częstości występowania oraz czasu trwania.

Czasami chorzy z nieswoistymi chorobami zapalnymi jelit czują się zmęczeni. Określenie „zmęczenie” jest używane w całym kwestionariuszu. Zmęczenie zostało określone jako poczucie ciągłego znużenia, z okresami nagłego i przytłaczającego braku energii lub uczucia wyczerpania, które nie ustępują pomimo odpoczynku lub snu.

\begin{tabular}{|c|c|c|c|c|c|}
\hline \multirow{3}{*}{$\begin{array}{l}\text { Proszę zaznaczyć jedną cyfrę dla każdego z pytań. } \\
\text { Jaki jest Pani (Pana) poziom zmęczenia W TYM MOMENCIE }\end{array}$} & \multicolumn{5}{|c|}{ Punktacja w skali 0-4, gdzie } \\
\hline & \multicolumn{3}{|c|}{$0=$ brak zmęczenia } & \multicolumn{2}{|c|}{4 = silne zmęczenie } \\
\hline & 0 & 1 & 2 & 3 & 4 \\
\hline $\begin{array}{l}\text { Jaki był Pani (Pana) NAJWYŻSZY poziom zmęczenia w ciągu ostatnich } \\
2 \text { tygodni }\end{array}$ & 0 & 1 & 2 & 3 & 4 \\
\hline $\begin{array}{l}\text { Jaki był Pani (Pana) NAJNIŻSZY poziom zmęczenia w ciągu ostatnich } \\
2 \text { tygodni }\end{array}$ & 0 & 1 & 2 & 3 & 4 \\
\hline $\begin{array}{l}\text { Jaki był Pani (Pana) ŚREDNI poziom zmęczenia w ciągu ostatnich } \\
2 \text { tygodni }\end{array}$ & 0 & 1 & 2 & 3 & 4 \\
\hline $\begin{array}{l}\text { Przez jaką część czasu czuła (czuł) się Pani (Pan) zmęczona } \\
\text { (zmęczony) w ciągu ostatnich } 2 \text { tygodni }\end{array}$ & $\begin{array}{c}0 \\
\text { Wcale }\end{array}$ & $\begin{array}{c}1 \\
\text { Czasami }\end{array}$ & $\begin{array}{c}2 \\
\text { Często }\end{array}$ & $\begin{array}{l}3 \\
\text { Większość } \\
\text { czasu }\end{array}$ & $\begin{array}{l}4 \\
\text { Przez cały } \\
\text { czas }\end{array}$ \\
\hline
\end{tabular}

\section{Część II - Skala wpływu zmęczenia wywołanego chorobami zapalnymi jelit na codzienną aktywność}

Ta część kwestionariusza ocenia obserwowany wpływ zmęczenia na Pani (Pana) codzienną aktywność $\underline{\mathbf{w}}$ ciągu ostatnich 2 tygodni.

Proszę odpowiedzieć na wszystkie pytania. Możliwe odpowiedzi na pytania to: Wcale - 0; Czasami - 1; Często - 2; Przez większość czasu - 3; Przez cały czas - 4.

Jeśli któraś z wymienionych aktywności Pani (Pana) nie dotyczy, np. nie prowadzi Pani (Pan) samochodu, proszę wybrać ND (nie dotyczy).

\begin{tabular}{|c|c|c|c|c|c|c|}
\hline $\begin{array}{l}\text { Proszę wybrać tylko jedną odpowiedź na każde z pytań } \\
\text { w odniesieniu do ostatnich } 2 \text { tygodni. }\end{array}$ & Wcale & Czasami & Często & $\begin{array}{l}\text { Większość } \\
\text { czasu }\end{array}$ & Cały czas & $\begin{array}{l}\text { Nie } \\
\text { dotyczy }\end{array}$ \\
\hline $\begin{array}{l}\text { Musiałam (musiałem) się zdrzemnąć w ciągu dnia } \\
\text { z powodu zmęczenia }\end{array}$ & 0 & 1 & 2 & 3 & 4 & \\
\hline Zmęczenie uniemożliwiało mi udział w życiu towarzyskim & 0 & 1 & 2 & 3 & 4 & \\
\hline $\begin{array}{l}\text { Nie byłam (nie byłem) w stanie iść do pracy lub szkoły } \\
\text { z powodu zmęczenia }\end{array}$ & 0 & 1 & 2 & 3 & 4 & ND \\
\hline $\begin{array}{l}\text { Zmęczenie miało wpływ na moją wydajność w pracy } \\
\text { lub szkole }\end{array}$ & 0 & 1 & 2 & 3 & 4 & ND \\
\hline $\begin{array}{l}\text { Miałam (miałem) problemy z koncentracją } \\
\text { z powodu zmęczenia }\end{array}$ & 0 & 1 & 2 & 3 & 4 & \\
\hline $\begin{array}{l}\text { Miałam (miałem) problemy z motywacją } \\
\text { z powodu zmęczenia }\end{array}$ & 0 & 1 & 2 & 3 & 4 & \\
\hline
\end{tabular}




\begin{tabular}{|c|c|c|c|c|c|c|}
\hline $\begin{array}{l}\text { Proszę wybrać tylko jedną odpowiedź na każde z pytań } \\
\text { w odniesieniu do ostatnich } 2 \text { tygodni. }\end{array}$ & Wcale & Czasami & Często & $\begin{array}{l}\text { Większość } \\
\text { czasu }\end{array}$ & Cały czas & $\begin{array}{l}\text { Nie } \\
\text { dotyczy }\end{array}$ \\
\hline $\begin{array}{l}\text { Nie mogłam (nie mogłem) się umyć i ubrać } \\
\text { z powodu zmęczenia }\end{array}$ & 0 & 1 & 2 & 3 & 4 & \\
\hline $\begin{array}{l}\text { Miałam (miałem) kłopoty z poruszaniem się } \\
\text { z powodu zmęczenia }\end{array}$ & 0 & 1 & 2 & 3 & 4 & \\
\hline $\begin{array}{l}\text { Nie byłam (nie byłem) w stanie prowadzić samochodu, } \\
\text { ile potrzebowałam (potrzebowałem) z powodu zmęczenia }\end{array}$ & 0 & 1 & 2 & 3 & 4 & ND \\
\hline $\begin{array}{l}\text { Nie byłam (nie byłem) w stanie uprawiać tyle aktywności } \\
\text { fizycznej, ile chciałam (chciałem) z powodu zmęczenia }\end{array}$ & 0 & 1 & 2 & 3 & 4 & \\
\hline $\begin{array}{l}\text { Miałam (miałem) trudności w kontynuowaniu mojego } \\
\text { hobby lub zainteresowań z powodu zmęczenia }\end{array}$ & 0 & 1 & 2 & 3 & 4 & \\
\hline $\begin{array}{l}\text { Zmęczenie miało wpływ na mój związek emocjonalny } \\
\text { z partnerem (partnerką) }\end{array}$ & 0 & 1 & 2 & 3 & 4 & ND \\
\hline $\begin{array}{l}\text { Zmęczenie miało wpływ na moje życie seksualne } \\
\text { z partnerem (partnerką) }\end{array}$ & 0 & 1 & 2 & 3 & 4 & ND \\
\hline Zmęczenie miało wpływ na moje relacje z dziećmi & 0 & 1 & 2 & 3 & 4 & ND \\
\hline Miałam (miałem) zły nastrój z powodu zmęczenia & 0 & 1 & 2 & 3 & 4 & \\
\hline $\begin{array}{l}\text { Czułam (czułem) się odizolowana (odizolowany) } \\
\text { z powodu zmęczenia }\end{array}$ & 0 & 1 & 2 & 3 & 4 & \\
\hline Zmęczenie miało wpływ na moją pamięć & 0 & 1 & 2 & 3 & 4 & \\
\hline Popełniałam (popełniałem) błędy z powodu zmęczenia & 0 & 1 & 2 & 3 & 4 & \\
\hline $\begin{array}{l}\text { Z powodu zmęczenia czułam (czułem) się poirytowana } \\
\text { (poirytowany) }\end{array}$ & 0 & 1 & 2 & 3 & 4 & \\
\hline $\begin{array}{l}\text { Z powodu zmęczenia czułam (czułem) się sfrustrowana } \\
\text { (sfrustrowany) }\end{array}$ & 0 & 1 & 2 & 3 & 4 & \\
\hline Mylity mi się słowa z powodu zmęczenia & 0 & 1 & 2 & 3 & 4 & \\
\hline $\begin{array}{l}\text { Z powodu zmęczenia nie mogłam (nie mogłem) cieszyć } \\
\text { się życiem }\end{array}$ & 0 & 1 & 2 & 3 & 4 & \\
\hline Zmęczenie przeszkodziło mi w realizacji planów życiowych & 0 & 1 & 2 & 3 & 4 & \\
\hline Zmęczenie wpływało na moje poczucie własnej wartości & 0 & 1 & 2 & 3 & 4 & \\
\hline Zmęczenie wpływało na moją pewność siebie & 0 & 1 & 2 & 3 & 4 & \\
\hline $\begin{array}{l}\text { Zmęczenie sprawiało, że czułam (czułem) się } \\
\text { nieszczęśliwa (nieszczęśliwy) }\end{array}$ & 0 & 1 & 2 & 3 & 4 & \\
\hline $\begin{array}{l}\text { Miałam (miałem) problemy ze snem nocnym } \\
\text { z powodu zmęczenia }\end{array}$ & 0 & 1 & 2 & 3 & 4 & \\
\hline $\begin{array}{l}\text { Zmęczenie wpłynęło na moją zdolność wykonywania } \\
\text { zwykłych obowiązków domowych }\end{array}$ & 0 & 1 & 2 & 3 & 4 & \\
\hline $\begin{array}{l}\text { Musiałam (musiałem) prosić innych o pomoc } \\
\text { z powodu zmęczenia }\end{array}$ & 0 & 1 & 2 & 3 & 4 & \\
\hline Zmęczenie miało wpływ na moją jakość życia & 0 & 1 & 2 & 3 & 4 & \\
\hline
\end{tabular}




\section{Część III - Dodatkowe pytania o Pani (Pana) zmęczeniu}

Jak Pani (Pan) sądzi, co jest główną przyczyną odczuwanego zmęczenia poza chorobą zapalną jelit?

Jakie są według Pani (Pana) inne przyczyny Pani (Pana) zmęczenia?

Czy znalazła (znalazł) Pani (Pana) jakieś sposoby radzenia sobie ze zmęczeniem?

Jak długo odczuwa Pani (Pan) zmęczenie?

....... lat ........ miesięcy

W tym okresie Pani (Pana) zmęczenie miało charakter:

a) Stały

b) Okresowy

Oryginalna wersja skali IBD-F - Czuber-Dochan W, Norton C, Bassett P, et al. Development and psychometric testing of inflammatory bowel disease fatigue (IBD-F) patient self-assessment scale. J Crohn's Colitis 2014; 8: 1398-406. 